\title{
In the process of urbanization ethnic song and dance aesthetic builds correctly --- "flowers" song and dance in Ningxia as an example to present
}

\author{
Aihua Guan \\ Music and Dance College, Beifang University of Nationalities, Yinchuan Ningxia, 750021, China
}

Keywords: Urbanization, National songs and dances, Aesthetics, Construction.

\begin{abstract}
Urbanization, which is one of the important means to realize the modernization of China's countryside, has the most remarkable influence on minority areas. It not only changes the traditional lifestyles and production modes for thousands of years but also changes people's understanding of their own traditional cultures and artistic aesthetics. Especially, with the influence of strong culture and market economy, national songs and dances are increasingly becoming the accessories to economy and are gradually losing their cultural function and social function. If this continues, the loss of such functions will directly mislead the aesthetics in national arts and even result in the collapse of the aesthetics. Therefore, how to protect and correctly construct the aesthetics of minority songs and dances under the trend of urbanization should not only be considered by the functional department but also considered and studied by the watchmen of traditional culture and national culture.
\end{abstract}

\section{Introduction}

The art of minorities' songs and dances is an important part of minority culture. Minority culture or culture is a definition of broad sense. The British, E.B.Tylor, the father of Anthropology regarded culture as "a complicated whole, including knowledge, belief, art, morality, law, custom and all abilities and habits obtained by human beings in the society." The art of minority song and dance, which is the material reflection of minority culture, consists of a nationality's cognition of the objective world, belief, morality and custom etc. besides, it is the link for inheritance of national cultural gene and the field domain to show the national spirit. The uniqueness in its expression style is the significant symbol for national mark. In addition, it is also closely related to minorities' daily life. In each important festival, singing and dancing are a way for collective revelry and unbosoming. In folk activities, not only the national songs and dances amuse people but also the symbolized ceremonies maximally embody a nationality's value and world view.

Under the representation of collective revelry, national songs and dances show people's enthusiasm toward life as well as the retrospection and inheritance of traditional culture. Besides, minority songs and dances are also one of the minorities' intangible cultural heritages. According to the definition made by UNESCO, the intangible cultural heritage includes the aspects below:

(1) Orally-spread legends and expressions, including the language which serves as the media of intangible cultural heritage

(2) Performing arts

(3) Social custom, etiquette and festival

(4) Knowledge and practices concerning nature and universe

(5) Traditional handcraft skills

Minority songs and dances, which are the deepening of minority people's spiritual world in their long-term life and production, are the perceptions and communications during the coexistence between a nationality and nature. In the previous Ningxia, due to the relatively harsh natural condition, people's productivity lagged behind relatively. However, the material deprivation leaded to that people paid more attention to enriching their spiritual world. Therefore, there are many national songs and dances in Ningxia, which is not a big place with big population. Especially, the Hui nationality's popular "Huaer" is most wonderful. People usually held a "Huaer" corroboree in a slack 
season. At a "Huaer" corroboree, people of all nationalities not only removed the fatigue arising from the poor material conditions but also temporarily relieved the constraint of some rules and prohibitions. They were collectively in a joyful state in the activities for several days and even over ten days. At this time, people were not overwhelmed by natural conditions but sang their desire for beautiful life.

National songs and dances are the links the internal cohesion of an ethnic group and also the carriers for equal cultural exchanges of all nationalities. Besides, national songs and dances not only enrich people's spiritual life but also undertake the obligation of social communicative function. In a cultural language environment, national songs and dances can make the same nationality of different regions to have closeness and sense of identity so that the internal cohesion of an ethnic group can be strengthened. There is piece of song and dance works with its performing form dating from the banquet of marriage o major festivals in the Hui nationality's songs and dances of Ningxia and it is called "the song of Hui people's banquet", which includes the majority of mild and tender tunes, beautiful and pleasant lyrics, joyful and quick rhythm, and joyous and lively atmosphere. The singer sings while dancing. Sometimes, when the song reaches the emotional part, people will unexpectedly sing together with the singer so that everyone present in the marriage scene can lose their mind in the song with happiness.

\section{Aesthetic features of minority songs and dances}

According to the analysis on the aesthetic features of Ningxia Hui nationality's songs and dances, the following features of national songs and dances of all regions can be generally concluded:

1.Compositionality: National songs and dances are closely related to a nation's life. In reality, labor ceremonies, religious rites, weddings and funerals etc. all involve national songs and dances. According to the aesthetics of national songs and dances, some scenes and habits in life can be directly used in the singing and dancing performance. For instance, some tunes of the song of Hui people's banquet came from the tone of Quran read by the Akhoond. Multiple elements are ingeniously mingled and reproduced or exaggerated with the artistic techniques of expression.

2.Diversity: the development of national culture is not independent and is influenced by its surrounding cultures. The whole Chinese culture is composed of the cultures of all nationalities. For instance, the Huaer songs of Hui nationality not only have the shadow of Xintianyou but also include the melody of mountain-climbing tone.

3.Self-entertainment: The biggest characteristic of national songs and dances is the self-entertainment, which firstly aims to meet the need of the nation's spiritual pleasure, so this self-entertainment is completely not affected by any third party. It follows its own nation's aesthetic feeling for folk art and won't be changed according to the external world's likes or dislikes. The characteristic of self-entertainment is also the foundation for the independence of national songs and dances.

\section{Connotation and purpose of urbanization}

Urbanization is the historical process of non-agricultural industries' ceaseless gathering in cities and towns, rural population's continuous transfer to non-agricultural industries, cities and towns, transformation of rural areas into urban areas, increasing number of cities and towns and continuous expansion in their scales and the continuous spreading and diffusion of urban production modes and lifestyles and urban civilization to the rural areas with the industrialization development. It has the characteristics below: firstly, industrialization, informationization and urbanization; secondly, coordination among population, economy, resources and environment; thirdly, building the city pattern which is closely related to the regional economic development and industrial distribution. Fourthly, realizing the all-around development of human beings. Because of the huge force of industrialization and informationization in the process of urbanization, there are inevitably some conflicts and contradictions between urbanization and the material and humanistic environments, 
which are needed by national songs and dances to survive. These contradictions are the national songs and dances' instinctive defenses under the power cultural pressure. Of course, no one has the right to deprive other nationalities' appeal for improvements in their life quality. Therefore, cultural policymakers indeed need to carefully design and implement cultural policies while giving considerations to improving the life quality and reserving traditional cultures.

\section{Wholly keep the national songs and dances intact to maintain the "original flavor" of culture}

With the development of society, new concepts will be added into the aesthetics of national songs and dances, so the protection of national songs and dances should also follow this law. The reason for the existing huge vitality of national songs and dances is because of people's need in reality. If national songs and dances are kept intact, it may kill the fresh vitality of national songs and dances. Thus, the intact reservation is only applicable to the cultural type facing disappearance

\section{"Marketization" of minority songs and dances}

As the market economy and urbanization advance, the tourism industry is developing from cities to the vast habitations of minorities. In order to attract more tourists, all areas have gotten engaged in a new marketing mode of "building a stage with culture to developing economy". All repackaged national songs and dances go to various performance and tourism stages; national songs and dances have lost the cultural significance of their existence. As a result, "the cultural attribute of traditional art has been changed and the traditional art, which is a lifestyle of a specific ethnic group, has been changed into a mass consumption product resorting to the modern consumption culture". The "marketization" tendency of national songs and dances is a problem of understanding the cultural attribute in the process of urbanization.

\section{Problems in aesthetics of minority songs and dances during the process of urbanization}

During the process of urbanization, changes in production modes and lifestyles as well as the intervention of external powerful culture have certainly leaded to some changes in aesthetics in minority songs and dances. Some changes occur in the forms and more changes occur in minority people's understanding of their cultures and artistic inheritance. The changes are specifically embodied in the follow aspects:

1). Disappearance of the national character and endemicity of a language

2). Obvious enhancement in other-entertainment of dance

The primitive creative impulsion of minority songs and dances came from the exaggerated description on life. The audiences fell into two types: "human being" and "god". National songs and dances, which are an ethnic group's subjective impression for the objective world, belong to part of spiritual life and are private some times. However, in the process of urbanization, to rapidly attract tourists, some functional organizations pack the local minority songs and dances purposefully with the slogan of protecting culture. But this package completely neglects the need of national songs and dances to link relationships among ethnic groups, build the public relations in communities and enrich the public's life, and makes national songs and dances become pure commercial modes. The changes in the purpose of and context of performance shake the aesthetic foundation of national songs and dances.

3). Variation and disappearance of inheritance pattern

A complete inheritance mechanism is required to protect any culture from marginalization and disappearance. As the inheritance of cultural spirit is relatively stable, the inheritance from generation to generation should be continued in some basic modes and patterns. Such pattern may be altered during the process of urbanization. However, a change without understanding the foundation of the nation's culture may touch the kernel of cultural and artistic aesthetics. It probably will cause the artistic performance lose the support of its essential spirit and only reserve some showy and not substantial national elements. 


\section{Theoretical basis and methodology for the correct construction of aesthetics of minority songs and dances in the process of urbanization}

Because of region, culture, custom and belief etc., Chinese minorities have different aesthetic directions in their respective songs and dances. For instance, singing is emphasized in Hui nationality's songs and dances. However, some minorities are more inclined to express their feelings with dances; some minorities prefer the rough and bold singing style while others prefer the mild and meticulous singing style.

\section{Methodology for correct construction of aesthetics of minority songs and dances under urbanization}

Correct national cultural view: A national culture is the material reflection of the national spiritual world. China's diversified national cultures constitute the footstones of Chinese civilization. A correct national cultural view not only can eliminate the one-sided cognition of national culture in the process of urbanization but also is the important support for harmonious development of nations. As far as an ethnic group is concerned, an ethnic group can comprehensively and rationally understand its own art of song and dance by deeply understanding its own culture. Then, it won't lose its own aesthetic standard and judgment under the influence of the external powerful culture.

\section{Reasonable and feasible communication means and methods}

Of course, the emphasis on the correct construction of aesthetics of national songs and dances in the new era cannot be separated from the foundation of a nation's traditional culture. The change in lifestyle caused by urbanization also leaded to a great change in the context of national songs and dances. For example, as the number of Hui people engaged in agricultural cultivation decreases, the influence of agricultural culture is also changing toward the new roles and content reflecting the new life in songs is also growing. From the perspective of the history of artistic development, this is the law of art development. We should not only pay attention to the influence of communication means of urbanization on the aesthetics of traditional national songs and dances but also understand how to reasonably use such communication means. Reasonable application of such communication means can not only help a nationality to recognize its own culture but also carve out a way for other nations to better understand a nation's national art, so that they can develop jointly through mutual understanding.

\section{Basic conditions for correct construction of aesthetics of national songs and dances under urbanization}

It is true that everything has two sides. On the one hand, the extraneous cultures during the process of urbanization will cause impacts and digestion on the aesthetic principle and modes of national songs and dances. On the other hand, all resources brought by urbanization also consolidate the status of aesthetics of national songs and dances and also remove some outdated and backward aesthetics views from reality. These seemingly contradictory themes are actually unified.

1.The economic development in national regions provides a powerful material basis for the inheritance and development of aesthetics of national songs and dances.

2.The propulsion of the state's national cultural policies is the political guarantee for the theoretical and systematic construction of aesthetics of minority songs and dances under urbanization.

3.The national confidence brought by urbanization also brings new content in the aesthetics of national songs and dances.

\section{Approaches to correctly construct the aesthetics of national songs and dances under urbanization}


1).Insist on attaching most importance to exploring and protecting the excellent traditional aesthetics of national songs and dances

(1) Carry out a general investigation;

(2) Strengthen the construction of files.

2). Take enriching and absorbing excellent aesthetics as an auxiliary measure

Any culture cannot be isolated from the world and needs to absorb nutrient from other cultures. The attitude toward an extraneous culture tests a country's cultural confidence. If a country is more confident, it can treat extraneous cultures with a more active attitude. Extensively absorbing and integrating all excellent extraneous cultures is the necessary requirement to promote the prosperity in Chinese culture. The aesthetics of national songs and dances is also like this.

3).Cultivate artistic talents with both profound national cultural accomplishment and broad horizon

4).Enrich the traditional national aesthetics with modern technical means

Changes in traditional songs and dances and their aesthetics are not manipulations. Any culture needs to be in line with the development of era. Under the influence of urbanization, we only oppose the changes in the aesthetics and forms of national songs and dances for the purpose of pure commerce but we advocate that the modern sense in the forms of national songs and dances is the integration with the sense of the times. Only in this way, we can better pass on the essence and unique aesthetic sentiments of national songs and dances to more people.

\section{Conclusion}

Urbanization is a way for all minority areas to improve their life and production, but we should also see that people have the tendency to deny their own cultures due to the changes in the production relations in the process of urbanization. This is certainly related to the influence of powerful cultures but the most importance cause is the people's inadequate understanding of their own cultures and arts. Chinese art is composed of all national arts. We cannot divide arts into advanced ones and backward ones. An art, which can objective reflects a nation's past, modern and future spiritual worlds, is exactly a good one. The correct construction of aesthetics of minority songs and dances is not reconstruction but the careful retrospection and protection of a nationality's culture. Abandon those disagree with the development of the times and reserve those which are excellent and traditional. More importantly, we hope to achieve more harmony between the national aesthetics and the era with some new modern means and to enrich the spiritual world while changing the material life.

\section{Acknowledgement}

This paper is the result of Correct Construction of Minorities' Song and Dance Aesthetics in the Process of Urbanization - Taking the Current Song and Dance of "Huaer" of Ningxia for example, early training project of art of national social science fund of 2014 in Beifang University of Nationalities. Project No.: 2014QSYP02

\section{References}

[1] Taylor. Primitive Culture, Shanghai: Shanghai Literature and Art Publishing House, 1992, 1.

[2] Hong Xiumei and Liu Tongsheng. General View on Hui Nationality's Song of banquet in Northwest China, Ningxia: Ningxia People's Press, 200809 P36.

[3] Zhang Zhanbin. Strategic Significance and Reform Difficulty of New Urbanization, Journal of China National School of Administration, 201301 P48-54.

[4] Wu Xiao. Post-modern Characteristic of Text of Folk Art Performance, Journal of the Second College of Nationalities in Northwest China, 20081 P66-70. 
[5] Du Weixiong. Relation between Language and Music, Chinese Music,1990 -1 P16-19. 